\title{
Tax havens are the tip of the iceberg
}

To the Editor - Galaz et al. ${ }^{1}$ present a compelling analysis demonstrating the key role of tax havens in facilitating environmentally damaging economic activities, including illegal fishing. Within fisheries, Galaz et al. point out that $70 \%$ of the known vessels implicated in illegal, unreported and unregulated (IUU) fishing are, or have been, flagged under a tax haven jurisdiction. Their study highlights important policy implications: tax havens need to disclose beneficiary ownership and to stop practices that, in effect, subsidize environmental degradation.

We suggest that the use of tax havens is just one of many methods used to conceal illegal fishing activities. To illustrate this, we studied more than 2,800 offending vessels listed in the Criminal Record of Fishing Vessels database over the period from 2002 to 2018 (incomplete year). This database records all fishing vessels (and over 900 associated seafood companies) that have been caught, observed and/or sanctioned for engaging in any form of illegal activity worldwide (including IUU fishing), obtained from governmental records (public and confidential), geospatial fishing operations analysis, media reports and community informants. We found that less than $2 \%$ of fishing vessels caught or observed specifically engaging in IUU activities were flagged in tax haven jurisdictions at the time of the offence, and only $11 \%$ of the total number of offending vessels belonged to companies whose address was listed within a tax haven jurisdiction, as defined by Galaz and colleagues. This large discrepancy between Galaz et al. reporting that $70 \%$ of IUU vessels are flagged to tax haven jurisdictions and our results (only 2\%) stems from Galaz et al. relying on the list of blacklisted vessels by regional fisheries management organizations and the vessels for which a purple notice was issued by the International Criminal Police Organization (209 vessels), whereas the Criminal Record of Fishing Vessels includes all vessels that were caught or identified as involved in IUU within national, regional and high seas jurisdictions, whether or not they were blacklisted (2,800 vessels) and their associated companies or owners (900 companies).

Investigations of IUU fishing vessels indicate multiple practices that do not systematically involve tax havens, such as diversion ${ }^{2}$, flag hopping ${ }^{3}$ and transshipments ${ }^{4}$. It is likely that some IUU operators use yet further practices to conceal their activities, including acquisition of new assets (vessels, seafood companies, quota and licences) in areas with open markets ${ }^{5}$, multiplication of subsidiaries in non-taxhaven jurisdictions $s^{6}$, multiple layers of vessel management ${ }^{6}$, mislabelling of fish, increased transshipments at sea ${ }^{4}$, and shifting fishing operations to new areas.

Preventing the reflagging of fishing vessels to tax havens will complicate some IUU operations, but it will not address many of the other incentives that can contribute to diversion techniques. For example, much of the reflagging or flag hopping of IUU vessels is motivated by the tax credits provided by non-tax-haven jurisdictions. Complementary policy measures should thus generate costs to vessel owners that outweigh the profits from illegal fishing activities $^{7}$, such as through higher and more drastic sanctions ${ }^{8,9}$, and removal of subsidies from fishing fleet owners, including beneficial owners earning profits but hiding their ownership and identity to avoid taxation and criminal liability ${ }^{10}$. Additional measures should also seek to block highseas trade and transshipment routes of trade post-capture ${ }^{5}$, implement measures preventing IUU vessels from landing and laundering their catches through ports in countries that are signatory to the Port State Measures Agreement ${ }^{11}$, and more comprehensively list vessels, companies and beneficial owners involved in illegal fishing activities.

Dyhia Belhabib ${ }^{1 \star}$ and Philippe Le Billon ${ }^{2}$ ${ }^{1}$ I-Sea Fish, Community Fisheries, Ecotrust Canada, Vancouver, British Colombia, Canada. ${ }^{2}$ School for Public Policy and Global Affairs, University of British Colombia, Vancouver, British Colombia, Canada. *e-mail:Dyhia.belhabib@gmail.com

Published online: 15 October 2018 https://doi.org/10.1038/s41559-018-0704-2

\section{References}

1. Galaz, V. et al. Nat. Ecol. Evol 2, 1352-1357 (2018).

2. Österblom, H., Sumaila, U. R., Bodin, Ö., Sundberg, J. H. \& Press, A. J. PLoS ONE 5, e12832 (2010).

3. Miller, D. D. \& Sumaila, U. R. Mar. Policy 44, 204-211 (2014).

4. Miller, N. A., Roan, A., Hochberg, T., Amos, J. \& Kroodsma, D. A. Front. Mar. Sci. https://doi.org/10.3389/fmars.2018.00240 (2018).

5. Macdonald Witkin, T. Triggering a Diverse Seafood Diet: Exploring Perceptions of Sustainable Seafood Systems in New England. MSc thesis, Univ. Rhode Island (2018).

6. Griggs, L. \& Lugten, G. Mar. Policy 31, 159-168 (2007).

7. Sumaila, U. R., Alder, J. \& Keith, H. Mar. Policy 30, 696-703 (2006).

8. Cabral, R. B. et al. Nat. Ecol. Evol 2, 650-658 (2018).

9. Doumbouya, A. et al. Front. Mar. Sci. https://doi.org/10.3389/ fmars.2017.00050 (2017).

10. Sala, E. et al. Sci. Adv. 4, eaat2504 (2018).

11. Molenaar, E. J. in Recasting Transboundary Fisheries Management Arrangements in Light of Sustainability Principles (eds Russell, D. A. \& VanderZwaag, D. L.) 369-386 (Martinus Nijhoff, Leiden, 2010).

Competing interests

The authors declare no competing interests. 